\title{
Prevalence of Serum IgG Antibodies to Cystic Echinococcus Antigen among Patients in an Uzbekistan Emergency Hospital
}

\author{
Se Jin Park', Sung Sik Han', Khikmat Anvarov², Abdukhakim Khajibaev², Min-Ho Choi³, Sung-Tae Hong ${ }^{3, *}$ \\ 1School of Life Sciences and Biotechnology, Korea University, Seoul 02841, Korea; '2Department of Surgery, Republican Research Center for \\ Emergency Medicine, Tashkent 100107, Uzbekistan; ' ${ }^{3}$ epartment of Parasitology and Tropical Medicine, Institute of Endemic Diseases, Seoul \\ National University, College of Medicine, Seoul 03080, Korea
}

\begin{abstract}
Cystic echinococcosis (CE) is one of the most widespread zoonotic helminthiases, which can last an asymptomatic infection for several years. The purpose of this study was to demonstrate serum antibody prevalence of $\mathrm{CE}$ among asymptomatic people in Uzbekistan using ELISA. A total of 2,547 serum samples were collected, 66 from confirmed CE patients and 2,481 of patients with other diseases than CE at a hospital in Tashkent, Uzbekistan. The serum samples were screened for CE specific lgG antibodies by ELISA using cystic fluid antigen obtained from sheep. The serum antibody positive rate was $89.4 \%(59 / 66)$ in CE and 3.6\% $(89 / 2,481)$ in other disease patients. The present ELISA recognized $89.4 \%$ sensitivity and $96.4 \%$ specificity. The ELISA absorbance of positive samples was distributed $0.271-$ 0.971 for CE and $0.273-0.887$ for other disease patients. The other disease patients with high absorbance over 0.3 were $50(2.0 \%)$ who were presumed to be active CE patients. The patients in their 40s showed the highest positive rate of $5.2 \%$ $(P=0.181)$, and women were $4.4 \%$ while men were $3.1 \%$ positive $(P=0.136)$. The data confirmed that there are many asymptomatic patients of CE in Tashkent. It is indicated that $C E$ is an endemic disease of public health importance in Uzbekistan.
\end{abstract}

Key words: Echinococcus granulosus, cystic echinococcosis, serum antibody, ELISA, positive rate, asymptomatic patient, Uzbekistan

\section{INTRODUCTION}

Cystic echinococcosis (CE) is the most important zoonotic helminthic disease which is mainly caused by the cystic cyclophyllidean cestode larva of Echinococcus granulosus [1]. CE is transmitted in several endemic countries widely from China to Central Asia and Northern Africa [1-3]. Its definitive host is the $\mathrm{dog}$, and the intermediate host is the sheep or other herbivorous mammals. Humans are an accidental intermediate host, infected in almost all organs or body parts by intake of contaminated food or water with eggs excreted from the final host [4]. At the initial stage of human $\mathrm{CE}$, the cyst grows very slowly for several years, and the patient is mostly asymptomatic dur-

- Received 14 October 2015, revised 26 November 2015, accepted 26 November 2015. *Corresponding author (hst@snu.ac.kr)

(c) 2015, Korean Society for Parasitology and Tropical Medicine

This is an Open Access article distributed under the terms of the Creative Commons Attribution Non-Commercial License (http://creativecommons.org/licenses/by-nc/3.0) which permits unrestricted non-commercial use, distribution, and reproduction in any medium, provided the original work is properly cited. ing that period. Its symptoms appear or complications may lead to serious illness and even to death when the cyst becomes a large mass [5]. Therefore, human $\mathrm{CE}$ is a serious chronic disease and most of the patients with symptoms require emergency surgical intervention in endemic areas $[6,7]$.

There have been a few studies investigating the prevalence of CE in Uzbekistan. Torgerson et al. [3] assumed a $0.7 \%$ serology positive rate in whole population to estimate 167,300 positive individuals in 2000. A recent study reported that surgical cases of CE were approximately 3,000 every year from 2002 to 2010 in 14 emergency hospitals over the country [6]. Since only a small part of human CE is suffering from clinical manifestations, most of the infected asymptomatic humans are unnoticed. It is necessary to identify how many population have asymptomatic $\mathrm{CE}$ in this endemic society.

The present study performed serological screening of CE among patients with $\mathrm{CE}$ and other diseases in an Uzbekistan emergency hospital using ELISA to investigate the proportion of asymptomatic infections. 


\section{MATERIALS AND METHODS}

\section{Serum samples from patients}

The study was conducted in the Republican Research Center for Emergency Medicine (RRCEM), Tashkent, Uzbekistan from 2008 to 2010. A total of 2,547 serum samples were collected and screened in this study. Of these, 66 were obtained from patients with CE who were confirmed by surgical intervention, and 2,481 were arbitrarily selected from individuals with other diseases which were requested for a serological test by other diseases. Among the 66 samples with $\mathrm{CE}$, 59 were also used for the previous study to develop ELISA [8]. All of the samples were transferred to the serology laboratory of Institute of Endemic Diseases, Seoul National University Medical Research Center, Seoul, Korea, and were kept frozen at $-70^{\circ} \mathrm{C}$ until used.

\section{ELISA}

The present study ELISA used the same method which was developed previously [8]. The procedure was carried out in polystyrene, flat bottomed 96-well microplates (Costar-Corning, Cambridge, California, USA). The plates were coated with $100 \mu \mathrm{l}$ of cystic fluid antigen in coating buffer and incubated overnight at $4^{\circ} \mathrm{C}$. Excess antigen was removed by washing the plates 5 times in $150 \mathrm{mM}$ PBS-Tween 20 (pH 7.2 PBST containing $0.05 \%$ Tween 20 ). The antigen-coated plates were blocked with $1 \% \mathrm{BSA}$ in PBST for $1 \mathrm{hr}$ at $37^{\circ} \mathrm{C}$, thereafter washed with PBST for 5 times. The tested serum samples were diluted 1:100 in PBST, and $100 \mu \mathrm{l}$ aliquots were added to each well and incubated for $2 \mathrm{hr}$ at $37^{\circ} \mathrm{C}$. After washing as before, anti-human IgG horseradish peroxidase (Cappel, West Chester, Pennsylvania,

Table 1. Demographic characteristics of subjected patients

\begin{tabular}{llccr}
\hline \multirow{2}{*}{ Parameters } & & \multicolumn{3}{c}{ No. of patients with $^{2}$} \\
\cline { 3 - 5 } Age $(\mathrm{yr})$ & \multicolumn{2}{c}{ CE } & Other diseases $^{\mathrm{a}}$ & Total \\
& $20-29$ & 1 & 202 & 203 \\
& $30-39$ & 6 & 442 & 450 \\
& $40-49$ & 3 & 347 & 353 \\
& $50-59$ & 1 & 387 & 390 \\
& $60-69$ & 0 & 450 & 451 \\
& $70-79$ & 1 & 361 & 361 \\
Sex & $\geq 80$ & 1 & 218 & 219 \\
& Men & 8 & 62 & 63 \\
Unidentified & & & 1,088 & 1,096 \\
Total & & 7 & 1,059 & 1,066 \\
\hline
\end{tabular}

${ }^{a}$ Other diseases include hepatitis, gallstones.

${ }^{\mathrm{b}}$ The 387 patients were unidentified for age and sex.
USA) diluted 1:24,000 in PBST were added to each well and incubated for $1 \mathrm{hr}$ at $37^{\circ} \mathrm{C}$ and then washed with PBST. Followed by incubation with $100 \mu \mathrm{l}$ tetramethyl benzidine (TMB; Pierce, Rockford, Illinois, USA) as the substrate solution, the reaction was terminated with $4 \mathrm{~N}$ sulphuric acid $\left(\mathrm{H}_{2} \mathrm{SO}_{4}\right)$. The absorbance was measured at $450 \mathrm{~nm}$ using the microplate reader, and the absorbance of 0.270 was set as the cut off point based on ELISA reaction as described before [8].

\section{Statistical analysis}

The data were analyzed using Statistical Package for Social Science (SPSS) version 23.0. The chi-square test was used in order to determine the significance in prevalence by the variables. $P$-values $<0.05$ were considered significant.

\section{RESULTS}

Demographic data of subjects are presented in Table 1. They were at the age from 15 to 84 years. Among the $66 \mathrm{CE}$ patients, 59 (89.4\%) were serum antibody positive, while 89 (3.6\%) were serologically positive out of 2,481 patients with other diseases (Table 2). The sensitivity and the specificity of the present ELISA were 89.4\% (59/66) and 96.4\% (2,392/2,481), respectively.

The age and sex distribution of serum antibody positive patients with other diseases are summarized in Table 3. By age, the positive rate was $5.2 \%(P=0.362)$ in $40-49$ years, $4.9 \%$ $(P=0.362)$ in $60-69$ years, and $2.7 \%(P=0.515)$ in $70-79$ years but all of the positive rates by age were not significant. The serum antibody positive rate was $4.4 \%$ in women and $3.1 \%$ in men, which was not statistically significant $(P=0.272)$.

The ELISA absorbance of positive reactions was in the range of 0.271-0.971 (median 0.363) among CE patients and 0.2730.887 (median 0.312) in those with other diseases (Fig. 1). The number of patients with absorbance of over 0.3 was 45 (68.2\%) among the $\mathrm{CE}$ and 50 (2.0\%) in other disease patients.

Table 2. Serology findings of patients with CE and other diseases by ELISA

\begin{tabular}{lrcc}
\hline \multirow{2}{*}{ ELISA result } & \multirow{2}{*}{ Total } & \multicolumn{2}{c}{ No.(\%) of patients with } \\
\cline { 3 - 4 } & & CE & Other diseases \\
\hline Positive & 148 & $59(89.4)$ & $89(3.6)$ \\
Negative & 2,399 & $7(10.6)$ & $2,392(96.4)$ \\
Total & 2,547 & 66 & 2,481 \\
\hline
\end{tabular}

Sensitivity=89.4\% (59/66); specificity $=96.4 \%(2,392 / 2,481)(P<0.001)$. 
Table 3. ELISA positive rates by age and sex of patients with other disease

\begin{tabular}{|c|c|c|c|c|c|}
\hline Age/Sex & & $\begin{array}{c}\text { No. of } \\
\text { examination }\end{array}$ & $\begin{array}{l}\text { No. of } \\
\text { positive }\end{array}$ & $\begin{array}{l}\text { Positive } \\
\text { rate (\%) }\end{array}$ & $P$-value \\
\hline$<20$ & $\begin{array}{l}\text { Men } \\
\text { Women } \\
\text { Total }\end{array}$ & $\begin{array}{r}108 \\
83 \\
191\end{array}$ & $\begin{array}{l}2 \\
5 \\
7\end{array}$ & $\begin{array}{l}1.9 \\
6.0 \\
3.7\end{array}$ & 0.128 \\
\hline $20-29$ & $\begin{array}{l}\text { Men } \\
\text { Women } \\
\text { Total }\end{array}$ & $\begin{array}{l}229 \\
157 \\
386\end{array}$ & $\begin{array}{r}4 \\
6 \\
10\end{array}$ & $\begin{array}{l}1.7 \\
3.8 \\
2.6\end{array}$ & 0.207 \\
\hline $30-39$ & $\begin{array}{l}\text { Men } \\
\text { Women } \\
\text { Total }\end{array}$ & $\begin{array}{l}163 \\
142 \\
305\end{array}$ & $\begin{array}{r}5 \\
5 \\
10\end{array}$ & $\begin{array}{l}3.1 \\
3.5 \\
3.3\end{array}$ & 0.824 \\
\hline $40-49$ & $\begin{array}{l}\text { Men } \\
\text { Women } \\
\text { Total }\end{array}$ & $\begin{array}{l}166 \\
159 \\
325\end{array}$ & $\begin{array}{r}6 \\
11 \\
17\end{array}$ & $\begin{array}{l}3.6 \\
6.9 \\
5.2\end{array}$ & 0.181 \\
\hline $50-59$ & $\begin{array}{l}\text { Men } \\
\text { Women } \\
\text { Total }\end{array}$ & $\begin{array}{l}183 \\
204 \\
387\end{array}$ & $\begin{array}{r}9 \\
5 \\
14\end{array}$ & $\begin{array}{l}4.9 \\
2.5 \\
3.6\end{array}$ & 0.194 \\
\hline $60-69$ & $\begin{array}{l}\text { Men } \\
\text { Women } \\
\text { Total }\end{array}$ & $\begin{array}{l}132 \\
174 \\
306\end{array}$ & $\begin{array}{r}5 \\
10 \\
15\end{array}$ & $\begin{array}{l}3.8 \\
5.7 \\
4.9\end{array}$ & 0.432 \\
\hline $70-79$ & $\begin{array}{l}\text { Men } \\
\text { Women } \\
\text { Total }\end{array}$ & $\begin{array}{r}85 \\
101 \\
186\end{array}$ & $\begin{array}{l}3 \\
2 \\
5\end{array}$ & $\begin{array}{l}3.5 \\
2.0 \\
2.7\end{array}$ & 0.515 \\
\hline$\geq 80$ & $\begin{array}{l}\text { Men } \\
\text { Women } \\
\text { Total }\end{array}$ & $\begin{array}{l}19 \\
36 \\
55\end{array}$ & $\begin{array}{l}0 \\
2 \\
2\end{array}$ & $\begin{array}{l}0 \\
5.6 \\
3.6\end{array}$ & 0.295 \\
\hline Total & $\begin{array}{l}\text { Men } \\
\text { Women } \\
\text { Total }\end{array}$ & $\begin{array}{l}1,085 \\
1,056 \\
2,141\end{array}$ & $\begin{array}{l}34 \\
46 \\
80\end{array}$ & $\begin{array}{l}3.1 \\
4.4 \\
3.7\end{array}$ & 0.136 \\
\hline Unidentified & & 340 & 9 & 2.6 & \\
\hline Total & & 2,481 & 89 & 3.6 & \\
\hline
\end{tabular}

\section{DISCUSSION}

The present study recognized that the serum antibody positive rate of patients with other diseases than CE was $3.6 \%$ in Uzbekistan. The patients with other diseases included all diagnosis except CE at an emergency hospital, RRCEM in Tashkent, Uzbekistan. This positive rate does not represent the exact prevalence in general population but demonstrates that 3.6\% of the RRCEM patients have serum antibodies to the antigen of E. granulosus. It is much higher than $0.7 \%$ of a previous report [3]. The difference should be considered by methods of serology and target subjects. Since the RRCEM is a general hospital to care for emergency patients in Tashkent, the present finding suggests that at least $3.6 \%$ of citizens of Tashkent or suburbs may be potential patients of CE.

The antibodies in positive serum to CE antigen by ELISA exactly demonstrate exposure history to the antigen of E. granulosus. Among 66 confirmed CE patients, 59 were also included

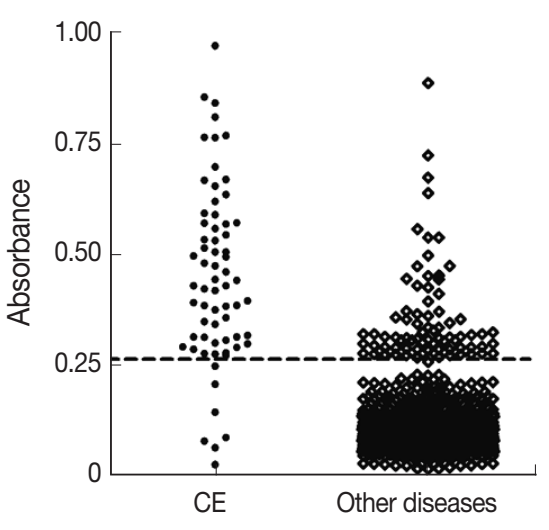

Fig. 1. Distribution of ELISA absorbance to cystic Echinococcus antigen of $\mathrm{CE}$ and other diseases patients. The cut-off OD value was 0.27 and was indicated by the dotted line.

in our previous study [8]. In that study, $91.5 \%$ sensitivity and $96.0 \%$ specificity were achieved [8], which were almost the same as those of the present study. Considering that the diagnostic sensitivity of ELISA was $89.4 \%$ and the specificity was $96.4 \%$ in the present study, about $10 \%$ of the examined subjects with CE were unrecognized by ELISA due to false negative reactions. Some patients with $\mathrm{CE}$ are known to demonstrate undetectable immune responses [9]. The 7 negatives of the 66 CE patients may be caused by chronic status of CE or unknown host factors. It is difficult to explain the reason of the false negative reaction but the present serology negative finding suggests that some patients are not immunologically stimulated by CE [9]. Moreover, based on a previous report about ELISA [10], those diagnostic parameters were acceptable.

On the other hand, 89 of the 2,481 patients with other diseases were positive by ELISA. Since other cross-reacting helminthiases are rare, false positive reaction is of little significance in Uzbekistan [8]. Therefore, most of the positive individuals with other diseases are presumed to be asymptomatic patients of CE. Some of them may be chronic, but some are in their early active stages of $\mathrm{CE}[1,7]$. Especially those with high absorbance must be active patients with CE. Of the 89 positive patients with other diseases, $50(2.0 \%)$ revealed absorbance over 0.3 which meant strong positive reactions. The strong serology reaction indicates that they are active but asymptomatic CE patients. It was impossible to trace their clinical status in this study. Nonetheless, most of the ELISA positive individuals may become potentially clinical CE patients in the future, which means its significance in public health points of view. The epidemiological and clinical significance of positive serum 
Table 4. Summary of serology positive rates reported from endemic regions

\begin{tabular}{|c|c|c|c|c|c|}
\hline Countries & Regions & Year of exam. & No. of exam. & Positive rates (\%) & References \\
\hline Uzbekistan & $\begin{array}{l}\text { Tashkent (hospital) } \\
\text { General population }\end{array}$ & $\begin{array}{l}\text { 2008-2010 } \\
2006 \text { (publication year) }\end{array}$ & $\begin{array}{l}2,481 \\
\text { Unknown }\end{array}$ & $\begin{array}{l}3.6 \\
0.7\end{array}$ & $\begin{array}{c}\text { Present study } \\
\text { [3] }\end{array}$ \\
\hline Iran & $\begin{array}{l}\text { Kerman (village) } \\
\text { Yansuj (health centers) } \\
\text { Meshkinshahr (health centers) }\end{array}$ & $\begin{array}{l}2006-2008 \\
2009 \text { (publication year) } \\
2011 \text { (publication year) }\end{array}$ & $\begin{array}{r}1,062 \\
500 \\
670\end{array}$ & $\begin{array}{l}7.3 \\
7.2 \\
1.8\end{array}$ & $\begin{array}{l}{[11]} \\
{[12]} \\
{[13]}\end{array}$ \\
\hline Turkey & $\begin{array}{l}\text { Denizli (township) } \\
\text { Manisa (university) }\end{array}$ & $\begin{array}{l}2009 \\
2013 \text { (publication year) }\end{array}$ & $\begin{array}{l}1,133 \\
2,034\end{array}$ & $\begin{array}{l}6.9 \\
2.1\end{array}$ & $\begin{array}{l}{[14]} \\
{[15]}\end{array}$ \\
\hline Libya & Northern region (village) & 1999 (publication year) & 10,096 & 11.2 & [16] \\
\hline China & $\begin{array}{l}\text { Ningxia (hospital) } \\
\text { Sichuan (township) }\end{array}$ & $\begin{array}{l}1994-2001 \\
2001-2008\end{array}$ & $\begin{array}{r}1,357 \\
10,186\end{array}$ & $\begin{array}{l}4.6 \\
3.2\end{array}$ & $\begin{array}{l}{[17]} \\
{[18]}\end{array}$ \\
\hline
\end{tabular}

antibodies must be determined by further studies.

Several studies investigated serum antibody prevalence of $\mathrm{CE}$ in endemic countries. The antibody positive rates were described as $0.7 \%$ in Uzbekistan [3], 1.8-7.3\% in Iran [11-13], 2.1-6.9\% in Turkey [14,15], 11.2\% in Libya [16], and 3.2-4.6\% in China $[17,18]$ (Table 4). The present positive rate of 3.6\% in Tashkent, Uzbekistan is rather in low range compared to those in other endemic countries but it is higher than the previously reported rate of $0.7 \%$ in Uzbekistan. Since Tashkent is a big capital city, the present positive rate must have been lower than that in rural areas in Uzbekistan. The number of patients with CE for emergency surgery was recorded mostly in Tashkent because Tashkent is the most populous city, and the emergency hospital in Tashkent is the largest in Uzbekistan [6]. CE must be transmitted more vigorously in rural provinces than in urbanized cities because the life cycle of $E$. granulosus is actively maintained around sheep farms over the country. It is recommended to survey on the antibody positive rate in rural areas of Uzbekistan.

The present positive rates varied by age groups and sex. Women in the 40 s demonstrated $6.9 \%$ positive rate, which was the highest. Although 4.4\% women and 3.1\% men were positive, the positive rates by age or sex in this study were not statistically significant. Other studies in Iran, Turkey, and Libya reported higher seropositive rates or prevalence of CE in women than in men $[11,14,16]$. Although the difference was not significant, it is assumed that women and children are exposed more to infections with CE in their life in Central Asia [3].

The present study had some limitations. All of the subjects were patients of RRCEM, Tashkent. Therefore the present positive rate of 3.6\% does not represent that of the general population. All of the subjected patients aged over 15, and the age and sex distribution was incomplete. A well-designed field co- hort study is required to determine the national prevalence of $\mathrm{CE}$ and to estimate its real figure of asymptomatic infections and clinical patients in Uzbekistan.

In conclusion, $3.6 \%$ of the patients at a general emergency hospital in Tashkent, Uzbekistan were positive for serum antibodies to CE. Most of them may be asymptomatic patients of $\mathrm{CE}$ and this implicates its significance in public health.

\section{ACKNOWLEDGMENTS}

The authors appreciate the Serology Laboratory of RRCEM, Tashkent, Uzbekistan, for collection of serum samples, and Ms. Hye Seong Kim, Institute of Endemic Diseases, Seoul National University, Seoul, Korea for her technical assistance of ELISA.

\section{CONFLICT OF INTEREST}

We have no conflict of interest related to this study.

\section{REFERENCES}

1. McManus DP, Zhang W, Li J, Bartley PB. Echinococcosis. Lancet 2003; 362: 1295-1304.

2. Ito A, Urbani C, Jiamin Q, Vuitton DA, Dongchuan Q, Heath DD, Craig PS, Zheng F, Schantz PM. Control of echinococcosis and cysticercosis: a public health challenge to international cooperation in China. Acta Trop 2003; 86: 3-17.

3. Torgerson PR, Oguljahan B, Muminov AE, Karaeva RR, Kuttubaev OT, Aminjanov M, Shaikenov B. Present situation of cystic echinococcosis in Central Asia. Parasitol Int 2006; 55 (Suppl): 207-212.

4. Daş T, Özer M, Yağmur G, Yildirim M, Özgün A, Demirel H. Hydatid Disease Involved in the Heart, Liver, and Kidney That Caused Sudden Death: case report. Am J Forensic Med Pathol 
2015; [Epub ahead of print].

5. Torgerson PR, Budke CM. Echinococcosis--an international public health challenge. Res Vet Sci, 2003; 74: 191-202.

6. Hong ST, Jin Y, Anvarov K, Khadjibaev A, Hong S, Ahmedov Y, Otaboev U. Infection status of hydatid cysts in humans and sheep in Uzbekistan. Korean J Parasitol 2013; 51: 383-385.

7. Siracusano A, Teggi A, Ortona E. Human cystic echinococcosis: old problems and new perspectives. Interdiscip Perspect Infect Dis 2009; 2009 doi: 10.1155/2009/474368.

8. Jin Y, Anvarov K, Khajibaev A, Hong S, Hong ST. Serodiagnosis of echinococcosis by ELISA using cystic fluid from Uzbekistan sheep. Korean J Parasitol 2013; 51: 313-317.

9. Moro P, Schantz PM. Echinococcosis: a review. Int J Infect Dis 2009; 13: 125-133.

10. Zhang W, McManus DP. Recent advances in the immunology and diagnosis of echinococcosis. FEMS Immunol Med Microbiol 2006; 47: 24-41.

11. Harandi MF, Moazezi SS, Saba M, Grimm F, Kamyabi H, Sheikhzadeh F, Sharifi I, Deplazes P. Sonographical and serological survey of human cystic echinococcosis and analysis of risk factors associated with seroconversion in rural communities of Kerman, Iran. Zoonoses Public Health 2011; 58: 582-588.

12. Sarkari B, Sadjjadi SM, Beheshtian MM, Aghaee M, Sedaghat F. Human cystic echinococcosis in Yasuj District in Southwest of Iran: an epidemiological study of seroprevalence and surgical cases over a ten-year period. Zoonoses Public Health 2010; 57:
146-150.

13. Heidari Z, Mohebali M, Zarei Z, Aryayipour M, Eshraghian M, Kia E, Shodajei S, Abdi J, Rakhshanpour A, Rokni M. Seroepidemiological study of human hydatidosis in meshkinshahr district, ardabil province, iran. Iran J Parasitol 2011; 6: 19-25.

14. Akalin S, Kutlu SS, Caylak SD, Onal O, Kaya S, Bozkurt AI. Seroprevalence of human cystic echinococcosis and risk factors in animal breeders in rural communities in Denizli, Turkey. J Infect Dev Ctries 2014; 8: 1188-1194.

15. Kilimcioğlu AA, Girginkardeşler N, Korkmaz M, Özkol M, Düzgün F, Östan I, Pabuşcu Y, Dinç G, Ok UZ. A mass screening survey of cystic echinococcosis by ultrasonography, Western blotting, and ELISA among university students in Manisa, Turkey. Acta Trop 2013; 128: 578-583.

16. Shambesh MA, Craig PS, Macpherson CN, Rogan MT, Gusbi AM, Echtuish EF. An extensive ultrasound and serologic study to investigate the prevalence of human cystic echinococcosis in northern Libya. Am J Trop Med Hyg 1999; 60: 462-468.

17. Yang YR, Sun T, Li Z, Li X, Zhao R, Cheng L, Pan X, Craig PS, Vuitton DA, McManus DP. Echinococcosis, Ningxia, China. Emerg Infect Dis 2005; 11: 1314-1316.

18. Li T, Chen X, Zhen R, Qiu J, Qiu D, Xiao N, Ito A, Wang H, Giraudoux P, Sako Y, Nakao M, Craig PS. Widespread co-endemicity of human cystic and alveolar echinococcosis on the eastern Tibetan Plateau, northwest Sichuan/southeast Qinghai, China. Acta Trop 2010; 113: 248-256. 
